Florida A\&M University College of Law

Scholarly Commons @ FAMU Law

Illegal Peace? Power Sharing with Warlords in Africa

Jeremy I. Levitt

Follow this and additional works at: https://commons.law.famu.edu/faculty-research

Part of the International Law Commons, and the Military, War, and Peace Commons 


\title{
Illegal Peace? Power Sharing with Warlords in Africa
}

\author{
By Jeremy Levitt*
}

The price of apathy towards public affairs is to be ruled by evil men.

- Plato

This paper examines the legality of power-sharing in Africa with specific reference to the Accra and Lomé accords, which brought about a fragile cessation of the conflicts in Liberian and Sierra Leone, respectively. It examines the future of international criminal law vis-à-vis power-sharing by prospectively examining gaps in state practice and rules that arguably permit the "crime of illegal peace" by insurrectionists, political elites, and moral guarantors. ${ }^{1}$

When warlords use violence to coerce democratically constituted governments to share power, does power-sharing simply become a euphemism for "guns for jobs"? Which legal rules, if any, govern peace agreements in internal conflicts? Specifically, which rules regulate power-sharing? Are the aims of peace, justice, and adherence to the rule of law attainable, let alone compatible, with coerced political transitions where warlords violently force democratically constituted or legitimate governments to share power? Should international law criminalize political elites that share power with warlords and rebels that have committed gross human rights and humanitarian law violations?

Consider this scenario: a rebel group, through brutal force, coerces a democratically elected government into a power-sharing arrangement that not only refashions the constitution of the order, but confers on the rebels unconditional amnesty, key government positions, and other privileges. Although the incumbent government prefers to punish the rebels rather than negotiate with them, it shares power out of political necessity and expediency because it lacks the muscle to defeat the rebels on the battlefield and the status or legitimacy to mobilize international military assistance to impose its political prerogatives. The failure to negotiate a cessation of hostilities inevitably results in prolonged conflict, anarchy, and the eventual toppling of the government.

Variations on this scenario have been commonplace in Africa for decades. Governments that have been violently and successfully challenged from within, but are still recognized as the de jure representative of the state, are faced with the quandary of how best to negotiate peace, maintain security, survive politically, and manage future uncertainties. They are forced to make strategic choices that often create normative friction between what is legal on one hand and what is politically necessary and expedient on the other. Should peace-brokers be held accountable for negotiating arrangements that violate fundamental rights? To date, political scientists, who tend to be proponents of power-sharing and seem to ignore the rule and role of law in political transitions, have controlled the debate over the legitimacy of power-sharing, which unfortunately has slipped under the radar of international lawyers.

This paper was inspired by the apparent disregard for the sanctity of the rule of law in the literature on power-sharing and among decision-makers, who seem to discount its relevance altogether-especially those responsible for negotiating the Accra and Lomé accords, which arguably prescribed illegal power-sharing irrespective of long-term social costs. To what extent, if any, does and should the rule of law influence the character of peace negotiations, agreements, and political transitions? To what extent should the rule of law sanction political

\footnotetext{
* Associate Professor, Director, Program for Human Rights \& Global Justice, Florida International College of Law.

${ }^{1}$ These remarks represent an abbreviated and modified version of an earlier essay, Jeremy I. Levitt, Illegal Peace? Examining the Legality of Power-sharing with Warlords and Rebels in Africa, 27 MICH. J. INT'L L. 495 (2006).
} 
elites that broker illegal peace agreements? This paper represents a conscientious attempt to address these questions and present a conceptual framework for examining the legal and political efficacy of coercing democratically constituted governments into sharing power. It seeks to define a lawful basis or approach to sharing power when governments are confronted with the aforementioned scenario, and again ponders whether those who share power should be held civilly or criminally liable when power is shared illegally.

This paper raises normative legal questions about the dominant logic that political powersharing is lawful, legitimate, and unequivocally serves the public good, arguing that powersharing deals that ignore controlling rules are unlawful and not viable. It centers on states emerging from civil conflict and focuses on the issue of power-sharing between democratically constituted governments, and warlords and rebels who have committed or participated in the commission of international crimes.

Power-sharing, as opposed to amnesty, for example, is the subject here. This is a critically important contribution given that power-sharing is more expansive and has a greater impact on sustainable peace than amnesty, which is conceptually and practically more narrow and, typically, a lesser but necessary element of power-sharing. In other words, amnesty may be given without sharing power, but power-sharing without amnesty is atypical. Amnesty applies to certain individuals and/or groups whereas power-sharing directly affects a state's entire population, as it reconstructs or reorders the framework of governance and its future disposition. This is why a discussion of the criminalization of illegal power-sharing is critically important as power-sharing arrangements are typically long-term and systemic and determine who will have a seat at the table of power, in what capacity, and for how long. This type of peace raises vital questions about the governance and developmental challenges faced by war-torn states.

The logic behind power-sharing assumes that rebels and warlords will behave and act as good citizens once they are given authoritative positions. It presupposes that warlords can become democrats once sanctioned with state authority. Power-sharing with warlords and rebels also sets a negative precedent, as it sends a dangerous message to would-be insurrectionists that violence is a legitimate means to effectuate change and obtain political power. For these reasons, the subject of power-sharing deserves distinct analysis, separate and apart from amnesty-particularly concerning its impact on the rule of law in post conflict societies.

I argue that when democratically constituted regimes are forced to choose between negotiating peace and being violently dislodged from power, peace agreements based on the rule of law should prevail over extralegal arrangements born out of political necessity and expediency. This is so because "legal peace" has fewer adverse impacts on the political order and is more sustainable than "illegal peace." Those deciding to share power should consider not simply political variables but also legal ones, as the law has an important regulatory role to play: it must constrain the political aspirations of decision-makers and ensure the lawfulness of peace deals. Political elites should be held civilly or criminally accountable for striking deals that grossly violate international law. The point is that the rules governing the legality of peace agreements must be adhered to, particularly when the beneficiaries of power-sharing acquired power undemocratically and unlawfully and are likely responsible for committing human atrocities. The logic underpinning this position raises several difficult questions for governments under siege: Who is responsible for internal disorder, repression, and postconflict justice? Is it immoral for a government to allow deadly conflict to continue until "legal peace" is reached? 
These questions raise several questions about when, if ever, leaders should accept "illegal peace." Should individual responsibility for repression be excused for the perceived collective good? Should power-sharing and amnesty take precedence over retributive justice? Should the political prerogatives of warlords and rebels supersede the fundamental civil, political, and human rights of their victims? I believe in a victims-based approach that seeks to hold political elites, whether professional warlords or members of government, responsible for entering into power-sharing arrangements that continue a culture of impunity through amnesty and sharing power.

\section{ARguments FOR PoWer-Sharing}

It may be argued that power-sharing is an effective way to give all parties stake in governance, and that the underlining goal is to give warring factions political legitimacy and decision-making authority in government with the hope they will stop fighting and take a vested interest in the vitality of the state. It follows that sharing power neutralizes violent conflict and that opening the political process serves a public good and makes an essential contribution to any transition to lasting peace.

It may further be argued that power-sharing is necessary in states embroiled in war and is often the only way to forestall conflict, restore the rule of law, strengthen societal support for government, and create the political space for democratic elections and transition. Without power-sharing, it is argued, rebels and warlords may have no incentive to negotiate peace and will return to the battlefield for fear of political, economic, and social disenfranchisement. Hence, governments share power to stop unwinnable wars. This type of reasoning supports the popular notion that peace without power-sharing may not be realistic or attainable.

\section{Arguments Against Power-Sharing}

The most fundamental argument against power-sharing appears in domestic, regional, subregional, and international law and policy: rebels, warlords, and other abusers who have sponsored or directed atrocities or sought to capture state power violently and undemocratically for economic rewards, political power, or any other reason have committed domestic and international crimes. It follows that peace agreements, irrespective of amnesty, should not empower these individuals to rule over their victims or wreak further havoc with the legitimacy of state authority. Peace brokers who proscribe such remedies, particularly those entrusted to protect the public good, should be held accountable for striking unlawful deals. This position holds peace-makers responsible for their actions by setting a standard for what is and is not legally permissible, and it rejects the ludicrous assumption, inherent in the practice, that warlords and rebels are intent on becoming practicing democrats, accepting instead the argument that power-sharing sends the signal to other would-be rebels that violence is a viable way to obtain political power. In this sense, power-sharing in postwar contexts connotes something far more difficult than sharing power with political opponents; it perhaps unrealistically necessitates a societal psychology of forgiveness and with it the ability of citizens to live and work peacefully with their enemies. Lastly, as is the case in Liberia and Sierra Leone, power-sharing may generate "feelings of distrust towards the new government and the political system, and encourage cynicism towards the rule of law."2 The hurdle of legitimacy, particularly as it relates to which factions will acquire authority

\footnotetext{
${ }^{2}$ Diba Majzub, Peace or Justice? Amnesties and the International Criminal Court, 3 MeLB. J. INT'L L. 251 (2002).
} 
over which key government portfolios (foreign affairs, defense, intelligence, internal security, justice, and natural resources), could undermine a peaceful political transition.

\section{The ACCRA AND Lomé ACCORDS}

The Accra and Lomé Accords are composed of thirty-seven articles with similar structure and content including cease-fire, military, human rights, implementation, and power-sharing components. The accords did not offer any legal basis or authority to legitimize their powersharing provisions but, rather, prescribed extra-legal rules and processes for sharing power that abrogated constitutionally based superior rules. The only legitimizing authority for power-sharing seems to have rested solely in the accords themselves. The accords not only violated state authority, fundamental rights, and executive and legislative power principles enshrined in constitution law, but also well-settled regional and international human rights law and emerging democracy norms. ${ }^{3}$

\section{CONCLUSION}

In conclusion, I argue that sharing power with warlords and rebels who unseat democratically constituted regimes is unlawful and that peace-makers have a legal obligation to comport with the rule of law in making peace deals. The failure to abide by controlling rules should result in civil, and even criminal, sanctions against peace brokers and the elites that endorse their prescriptions. This analysis, along with empirical studies, show that power sharing with warlords and rebels more often than not creates short-term fixes and long-term political instability resulting in continued conflict. In order to make a long-term and "legal peace," decision-makers should adhere to several principles when negotiating peace arrangements:

- take stock of all governing rules before beginning peace negotiations;

- allow governing rules to shape and influence the character of negotiations (i.e., what is legally permissible and what is not);

- work within, not outside, the existing legal framework, using governing rules as the minimum standard of acceptability;

- be unswerving in mediatory approaches by sending consistent messages to the relevant parties;

- seek timely international support for rule-based approaches using affirmative inducements such as recognition, aid, trade, and support in reforming the security sector;

- ensure that peacemakers remain in control of negotiations and implementation processes and do not allow warlords to retain vetoes and rewards;

- realize that the protection of human rights and democracy is integral, and not contrary, to security and remember that international law prevails over domestic peace accords in any conflict of law.

As Crocker and Hampson have noted, " $t \mathrm{t}] \mathrm{he}$ lesson, then, is to not permit military policies to become unhinged or detached from the broader [legal and] political purposes they are intended to serve." 4 Also, timidity in the face of armed militias is not effective-especially when the clock is working in their favor." 5 It is the concern over security and a resumption of war that provides the best rationale not to share power with warlords and rebels who will

${ }^{3}$ See generally id.

${ }^{4}$ Chester Crocke \& Fen Osler Hampson, Making Peace Settlements Work, Foreign PoL'y, Fall 1996, at 69.

${ }^{5}$ Id. 
undoubtedly inject criminal and predatory behavior into the political culture. International donors and multilateral organizations taking part in negotiation processes need to serve as legal-as opposed to moral-guarantors in order to ensure adherence to governing rules and protect fundamental legal rights. They should hold peace-makers civilly or criminally accountable for negotiating deals that violate fundamental human rights. States and multilateral institutions that sanction peace deals have a positive duty to protect human rights and democracy and not subvert them. 